\title{
ANALISIS KEPUTUSAN KONSUMEN DALAM PEMBELIAN SEPEDA MOTOR MEREK SUZUKI DI YOGYAKARTA
}

\author{
Arif Sudaryana, Grazia Desty Mustianingsih \\ Universitas PGRI Yogyakarta \\ J1. PGRI I No.117 Sonosewu, Yogyakarta. \\ e-mail: arifsudaryanaupy@gmail.com
}

\begin{abstract}
Abstrak
Penelitian ini bertujuan untuk menganalisis keputusan konsumen dalam pembelian sepeda motor Suzuki di Yogyakarta. Sampel yang dijadikan obyek penelitian sebanyak 98 responden pengguna sepeda motor Suzuki di Yogyakarta. Pengambilan sampel dalam penelitian ini dilakukan dengan metode sampel non probabilitas yaitu Purposive Sampling. Teknik pengumpulan data dilakukan dengan cara menggunakan kuisioner. Sedangkan teknik analisis yang digunakan dalam penelitian ini adalah analisis regresi linier berganda, dengan bantuan program SPSS versi 16,0. Hasil penelitian ini menunjukkan bahwa berpengaruh terhadap keputusan pembelian baik secara simultan dan parsial. Ditunjukkan pada nilai faktor harga, kualitas, desain, dan kenyamanan, secara parsial mempunyai pengaruh yang positif dan signifikan terhadap keputusan pembelian, dibuktikan dengan nilai t masing-masing sebesar 3,239( $\left.\mathrm{X}_{1}\right) ; 2,245\left(\mathrm{X}_{2}\right) ; 1,999\left(\mathrm{X}_{3}\right)$; $4,530\left(\mathrm{X}_{5}\right)$ dan nilai signifikansi yang kurang dari 0,05 masing-masing sebesar $0,002\left(\mathrm{X}_{1}\right) ; 0,026\left(\mathrm{X}_{2}\right) ; 0,048\left(\mathrm{X}_{3}\right)$ dan $0,000\left(\mathrm{X}_{5}\right)$. Variabel faktor kemudahan perawatan tidak memiliki pengaruh yang signifikan karena t sebesar 0,153 dengan nilai signifikansi 0,879 > 0,05. Hasil Uji $F$ dengan nilai $F_{\text {hitung }} 37.664$ dan signifikansi 0,000. Hasil ini membuktikan bahwa secara bersama-sama faktor harga, kualitas, desain, kemudahan perawatan dan kenyamanan berpengaruh terhadap keputusan pembelian. Dari hasil pengujian koefisien determinasi nilai $\mathrm{R}=0,820$ menunjukkan mempunyai hubungan yang kuat terhadap keputusan pembelian. Sedangkan nilai Adjusted $\mathrm{R}^{2}$ sebesar 0,654 hal ini berarti sebesar $65,4 \%$ menyumbangkan perubahan variabel $\mathrm{X}$ terhadap $\mathrm{Y}$ dan sisanya $34,6 \%$ tidak dijelaskan atau dipengaruhi oleh variabel lain yang tidak dimasukkan dalam model penelitian ini.
\end{abstract}

\section{Pendahuluan}

Persaingan di dunia perdagangan saat ini terbilang sangat ketat dan beragam. Apalagi dengan adanya pertumbuhan teknologi yang cukup pesat. Semakin majunya teknologi dalam berbagai bidang menuntut setiap orang atau lembaga (perusahaan) untuk selalu berkompetisi dalam rangka mencapai tujuan yang telah ditetapkan. Perkembangan teknologi ini juga merambah ke sektor transportasi, salah satunya adalah pada sektor otomotif yaitu sepeda motor. Sepeda motor merupakan alat transportasi yang membantu berbagai aktivitas manusia baik untuk kegiatan ekonomi, sosial dalam kegiatan sehari- hari. Perkembangan teknologi di bidang otomotif inilah yang menyebabkan banyak perusahaan otomotif menciptakan sepeda motor dengan berbagai model, desain yang menarik diimbangi dengan kualitas yang bagus dan harga yang cukup bersaing agar dapat mempertahankan kelangsungan hidupnya.

Tingginya kebutuhan masyarakat akan alat transportasi, menjadi peluang yang bagus bagi perusahaan otomotif, terutama di bidang sepeda motor. Kita ketahui bahwa sepeda motor sangat dibutuhkan oleh banyak orang, selain harganya terjangkau dan mudah dalam perawatannya. Saat ini banyak sekali bermunculan merek sepeda motor dengan berbagai model dan desain yang 
menarik dengan kualitas yang bagus pula. Cara untuk mendapatkannyapun tergolong mudah dengan harga di pasaran yang bersaing dari setiap merek. Di pasaran harga yang kompetitif merupakan potensi yang harus diperhatikan oleh perusahaan otomotif untuk dapat mempengaruhi keputusan pembelian konsumen.

Tingkat persaingan dalam dunia industri sepeda motor di Indonesia sekarang ini cukup ketat. Ada banyak industri otomotif yang terkait, tetapi hanya beberapa perusahaan yang menguasai pangsa pasar otomotif sepeda motor di Indonesia. Perusahaan-per- usahaan tersebut tergabung dalam anggota Asosiasi Industri Sepeda Motor Indonesia (AISI), di antaranya Honda, Yamaha, Suzuki, Kawasaki, TVS, Kazen. Berdasarkan data Asosiasi Industri Sepeda Motor Indonesia, penjualan sepeda motor nasional 2012 turun $11,2 \%$ dibandingkan tahun sebelumnya 8,034 juta unit menjadi 7,141 juta unit. Penurunan penjualan tahun lalu, memperbesar pangsa pasar Honda menjadi 57,31\% dari tahun lalu hanya 53,1\%. Yamaha menyusut lagi dari tahun lalu $(39,1 \%)$ menjadi $34,07 \%$, Suzuki 6,52\%, Kawasaki 1,84\% dan TVS $0,26 \%$.

Tabel 1. Data Penjualan Sepeda Motor Tahun 2012.

\begin{tabular}{lrrr}
\hline \multicolumn{4}{c}{ Penjualan Sepeda Motor 2012 } \\
\hline Merek & Desember & $\mathbf{2 0 1 2}$ & Pangsa (\%) \\
\hline Honda & 305.567 & 4.092 .693 & 57,31 \\
Yamaha & 139.809 & 2.433 .354 & 34,07 \\
Suzuki & 32.095 & 465.630 & 6,52 \\
Kawasaki & 10.404 & 13.1657 & 1,84 \\
TVS & 966 & 18.252 & 0,26 \\
\hline Total & $\mathbf{4 8 8 . 8 4 1}$ & $\mathbf{7 . 1 4 1 . 5 8 6}$ & $\mathbf{1 0 0}$ \\
\hline
\end{tabular}

Data AISI tahun 2012 menunjukkan market share penjualan motor di Indonesia dikuasai oleh Honda. Posisi Honda selalu menjadi pemimpin pasar, dengan total distribusi mencapai 4.092.693 unit. Rata-rata distribusi perbulan mencapai 341.058 unit. Di tempat kedua ada Yamaha dengan total distribusi mencapai 2.433.354 unit, rata-rata perbulan 202.780 unit. Suzuki menempati urutan ketiga dengan total penjualan selama tahun 2012 adalah 465.630 unit. Rata-rata penjualan perbulan 38.803 unit.

Berdasarkan data tersebut Honda menjadi market leader di pasar Indonesia. Suzuki hanya menguasai pasar sebesar 6,5\% dari total penjualan. Suzuki yang sejarahnya pada saat sepeda motor pertama kali menggunakan sistem 4 tak, pernah menjadi market leader kini ada di posisi ketiga, terpuruk jauh dibandingkan dengan Honda. Tetapi pasar sepeda motor Indonesia jauh dari kata bosan karena kebutuhan masyarakat untuk transportasi belum bisa dipenuhi transportasi publik. Ketidakpastian pembenahan sarana prasarana transportasi publik membuat sepeda motor masih menjadi alternatif pilihan utama, sehingga kebutuhan akan sepeda motor tetap akan meningkat seiring dengan perkembangan jumlah penduduk. Untuk itu ada peluang bagi sepeda motor Suzuki untuk meningkatkan penjualannya, memperbesar market share dengan melakukan kegiatan pemasaran yang lebih baik. Untuk menyusun kegiatan pemasaran yang lebih baik maka perlu diketahui faktor-faktor yang mempengaruhi konsumen dalam membeli sepeda motor Suzuki. Diharapkan dengan mengetahui faktor-faktor yang mempengaruhi keputusan konsumen dalam pembelian sepeda motor maka perusahaan melakukan inovasi sehingga Suzuki dapat kembali merajai penjualan sepeda motor di Indonesia. 


\section{Rumusan Masalah}

Berdasarkan latar belakang di atas, maka perlu untuk melakukan penelitian tentang "Analisis Keputusan Konsumen dalam Pembelian Sepeda Motor Merek Suzuki di Yogyakarta."

\section{Tujuan Penelitian}

Berdasarkan perumusan masalah di atas, maka penelitian ini terutama bertujuan untuk:

1. Mengidentifikasikan faktor-faktor yang mempengaruhi keputusan konsumen dalam pembelian sepeda motor Suzuki di Yogyakarta.

2. Menganalisis faktor yang paling dominan dalam keputusan pembelian konsumen sepeda motor Suzuki di Yogyakarta.

\section{Kajian Teori}

\section{Proses Keputusan Pembelian}

Perilaku konsumen dapat diartikan sebagai kegiatan-kegiatan individu yang secara langsung terlibat dalam mendapatkan dan mempergunakan barang dan jasa, termasuk di dalamnya proses pengambilan keputusan pada persiapan dan penentuan kegiatan-kegiatan tersebut. Perilaku konsumen adalah studi tentang bagaimana individu, kelompok dan organisasi memilih, membeli, menggunakan dan bagaimana barang, jasa, ide, atau pengalaman untuk memuaskan kebutuhan dan keinginan mereka menurut (Kotler dan Keller 2009). Perilaku konsumen merupakan tindakan individu yang secara langsung terlibat dalam mendapatkan, mengkonsumsi, dan menghabiskan produk dan jasa, termasuk proses pengambilan keputusan yang mendahului dan mengikuti tindakan-tindakan tersebut (Engel, et. al. 2004). Sehingga semua aktivitas yang dilakukan orang-orang ketika memilih, membeli dan menggunakan barang dan jasa untuk memuaskan kebutuhan dan keinginannya termasuk perilaku konsumen.

Keputusan individu atau seorang konsumen untuk memilih, produk tertentu untuk dibeli dan tidak membeli produk, adalah merupakan perwujudan keputusan konsumen dalam pembelian. Keputusan pembelian oleh konsumen, merupakan salah tahap dalam proses pengambilan keputusan pembelian yang komplek. Sedangkan proses pengambilan keputusan pembelian oleh konsumen ada beberapa tahap (Dharmmesta, 1993; Kotler, 2010) yaitu:

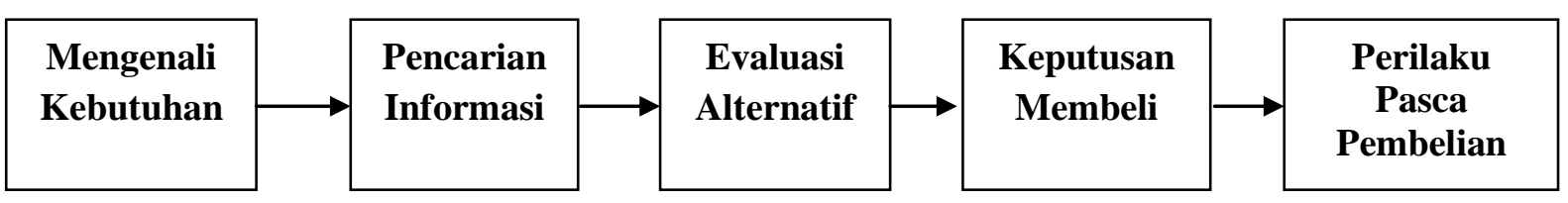

Gambar 1. Proses Pengambilan Keputusan Pembelian.

\section{Mengenali Kebutuhan}

Proses membeli diawali dengan kesadaran adanya masalah kebutuhan. Kebutuhan timbul karena perbedaan antara keadaan yang sesungguhnya dengan keadaan yang diinginkan. Kebutuhan akan menimbulkan kekuatan pada salah satu bagian otak untuk mengatur dan mengarahkan perilaku, akal dan tubuh agar dapat mempertahankan keadaan yang terbaik organisme itu (McNeal dan McDaniel, 1982, hal. 131). Kebutuhan yang dirasakan akan diekspresikan dalam perilaku pembelian dan konsumsi (Engel, Blackwell, Miniard, 1993. Hal. 269).

Tidak setiap kebutuhan yang disadari akan menjadikan organisme untuk melakukan tindakan selanjutnya (Engel, Blackwell, Miniard, 1993; Loudon and Della Bitta, 1993). Hasil dari pengenalan kebutuhan akan mendorong organisme untuk berperilaku 
lebih jauh sebagai pemecahan masalah jika kebutuhan yang dikenali cukup penting dan alat (produk) sebagai pemecahan masalah masih dalam batas kemampuannya. (Engel, Blackwell, Miniard. 1993). Dengan demikian dapat disimpulkan bahwa sesudah seseorang (konsumen) mengidentifikasi masalah, akan melakukan proses lebih lanjut dipengaruhi oleh tingkat pentingnya kebutuhan tersebut serta sumber daya yang dimiliki.

\section{Pencarian Informasi}

Setelah konsumen menyadari adanya masalah yang dirasakan, adanya kebutuhan serta kebutuhan tersebut dirasa sangat penting, sangat mendesak untuk dipenuhi maka konsumen akan mencari informasi berbagai produk yang potensial sebagai pemuas kebutuhan. Konsumen tidak akan membeli suatu produk jika produk tersebut tidak dapat memuaskan kebutuhannya. Sehingga konsekuensinya bahwa pencarian informasi didasari dengan tujuan untuk memperoleh, menemukan tentang produk dan segala sesuatu yang berkaitan dengan kebutuhannya.

Dalam pencarian informasi ini, konsumen dapat memperoleh informasi yang bersumber dari internal maupun eksternal. Sumber internal berkaitan kemungkinan adanya pengalaman di dalam memorinya yang berhubungan dengan situasi pembelian atas suatu produk. Di dalam pencarian informasi, ada beberapa faktor yang mempengaruhi, antara lain faktor situasi, faktor produk serta faktor konsumen. Kepercayaan dan sikap konsumen mempengaruhi dalam proses pencarian informasi. Jika konsumen sudah mempunyai sikap yang mendukung maka akan mencari informasi yang lebih banyak dengan memperhatikan manfaat dan biaya di dalam proses pencarian informasi.

Informasi yang lebih banyak dapat diperoleh konsumen melalui sumber eksternal seperti: (a). Sumber pribadi yang berasal dari teman, keluarga, tetangga maupun kenalan; (b). Sumber komersial yang dirancang oleh pemasar seperti iklan, wiraniaga, penyalur, pengemasan maupun penempatan pada rak toko (pajangan); (c). Sumber publik se- perti media massa ataupun organisasi konsumen yang ada.

\section{Evaluasi Alternatif}

Perolehan informasi tentang produk dari lingkungan akan memberikan banyak alternatif produk untuk dievaluasi yang sekiranya dapat memenuhi kebutuhannya. Evaluasi alternatif dapat diartikan sebagai proses evaluasi dari berbagai produk yang akan dipilih untuk dapat memenuhi kebutuhannya (Engel, Blackwell, Miniard, 1993). Di dalam evaluasi alternatif ini pada intinya adalah konsumen akan memilih produk di antara berbagai pilihan yang dapat memuaskan kebutuhannya. Konsumen akan melihat setiap produk adalah merupakan suatu himpunan dari ciri, atribut dan sifat tertentu yang mempunyai manfaat dan konsumen akan mencari manfaat-manfaat tertentu pada suatu produk. Manfaat suatu produk dapat dikategorikan ke dalam manfaat fungsional (functional benefit), manfaat praktis (practical benefit) dan perolehan emosional (emotional pay off) (Young and Feigen dalam Zeithaml, 1988). Berbagai manfaat tersebut akan berfungsi secara serentak yang akan diekspresikan sebagai variabel proses evaluasi alternatif produk yang terbaik bagi konsumen (Engel, Blackwell, Miniard, 1993). Sehingga, kebutuhan akan menentukan penilaian, pemikiran, kecenderungan, keinginan untuk berbuat dan melakukan tindakan bagi konsumen yang diperkirakan memiliki kemungkinan besar untuk memenuhi kebutuhan tertentu (Bayton, 1982 hal. 138).

Ada beberapa pendekatan dalam mengevaluasi alternatif produk seperti, Pendekatan Heuristic, Pendekatan Disjungtif, Pendekatan Leksikografis yang semuanya mengevaluasi produk berdasarkan atribut yang melekat pada produk disesuaikan dengan kebutuhan dan keinginannya. Seperti dalam pembelian komputer, yang diperhatikan antara lain kapasitas processor, memori, harga, ukuran berat. Sedangkan dalam pembelian sepeda motor, berdasarkan berbagai penelitian terdahulu, atribut yang diperhatikan antara lain: harga beli, harga jual ulang, 
pemakaian bahan bakar, desain, kenyamanan, kemudahan perawatan, kualitas.

\section{Keputusan Pembelian}

Setelah melalui proses evaluasi, konsumen akan membentuk preferensi di antara produk serta merek-merek yang menjadi pilihannya. Namun demikian apakah konsumen akhirnya membeli atau tidak, akan dipengaruhi oleh sikap orang lain atas produk tersebut serta faktor situasi yang tidak pernah terduga. Kedua faktor tersebut mempengaruhi maksud dan keputusan pembelian atas suatu produk. Hal ini menunjukkan bahwa interaksi sosial konsumen dapat mempengaruhi dalam keputusan pembelian. Besarnya pengaruh tersebut dipengaruhi oleh besarnya intensitas sikap orang lain tersebut serta besarnya dorongan yang ada pada konsumen untuk mengikuti pendapatnya.

\section{Perilaku Sesudah Pembelian}

Setelah membeli suatu produk, konsumen akan mengalami beberapa tingkatan kepuasan atau ketidakpuasan. Kepuasan merupakan fungsi dari dekatnya tidaknya antara harapan pembeli terhadap performance produk tersebut dengan persepsi pembeli atas performance yang diperoleh. Antara harapan atas performance dengan performance yang dirasakan sangat mungkin ada kesenjangan. Semakin jauh kesenjangan antara yang diharapkan dengan yang diperoleh akan menciptakan ketidakpuasan pada konsumen. Bagi konsumen yang puas mempunyai probabilitas membeli ulang yang lebih tinggi serta akan menginformasikan pada orang lain melalui getok tular (word of mouth). Sehingga bagi pemasar sangatlah besar peranan pembeli yang puas karena akan menjadi sumber informasi, periklanan yang gratis. Sedangkan bagi konsumen yang tidak puas akan mengurangi ketidakpuasan dengan berbagai macam cara, bisa mengembalikan, membuang atau mencari informasi yang menguatkan keputusan pembelian tersebut.

\section{Hipotesis}

Faktor harga, desain, kualitas, kemudahan dalam perawatan serta kenyamanan, baik secara parsial maupun bersama-sama mempunyai pengaruh yang siginifikan terhadap keputusan konsumen dalam pembelian sepeda motor merek Suzuki.

\section{Variabel Penelitian}

Sebagai variabel bebas dalam penelitian diukur dengan sub variabel antara lain: harga, kualitas, desain, kemudahan perawatan dan kenyamanan sedangkan variabel terikatnya adalah keputusan pembelian konsumen.

a) Harga, adalah pendapat/tanggapan konsumen atas sejumlah uang yang harus dikorbankan serta seberapa besar perhatian konsumen terhadap tingkat harga untuk mendapatkan sepeda motor Suzuki.

b) Kualitas, adalah pendapat/tanggapan konsumen atas kehandalan, tahan dikendarai sesuai dengan fungsinya.

c) Desain, adalah pendapat/tanggapan konsumen atas tampilan feature yang ada pada sepeda motor Suzuki.

d) Kemudahan Perawatan, adalah pendapat/ tanggapan konsumen dalam menjaga agar sepeda motor siap dipakai, jika rusak mudah diperbaiki.

e) Kenyamanan, adalah pendapat/tanggapan konsumen tentang yang dirasakan pada waktu mengendarai, tidak getar misalnya.

f) Keputusan pembelian, adalah keyakinan konsumen dalam memilih, menentukan pembelian sepeda motor merek Suzuki.

\section{Populasi dan Sampel}

Sebagai populasi dalam penelitian ini adalah mereka yang pernah melakukan pembelian sepeda motor Suzuki yang ada di Yogyakarta. Laju pertumbuhan penjualan sepeda motor di Yogyakarta mencapai 93. 849 unit roda dua sejak bulan Januari hingga Oktober tahun 2012 (Krjogja.com; 10 Desember 2012). 
Sedangkan penjualan sepeda motor $\mathrm{Su}-$ zuki tahun 2012 sebesar 6,5\% dari total penjualan sepeda motor di Indonesia. Sehingga dapat disimpulkan besaran populasi penjualan sepeda motor Suzuki adalah 6,5\% dari 93.849 yaitu 6100 unit.

Metode pengambilan sampel dalam penelitian ini menggunakan metode sampel non probabilitas yaitu Purposive Sampling. Penentuan besarnya sampel menggunakan rumus Slovin dalam Riduwan (2005:65), serta kelonggaran pengambilan sampel yang masih dapat ditolerir atau diinginkan, sebesar $10 \%$ yaitu sebagai berikut:

$$
\begin{gathered}
n=\frac{N}{1+N_{s} d^{2}} \\
n=\frac{6100}{1+6100 \cdot(1036)^{2}} ; n=98,38(98)
\end{gathered}
$$

Jadi jumlah sampel yang akan diteliti untuk menilai, bahwa motivasi mempengaruhi pembelian sepeda motor Suzuki sebanyak 98 pengguna.

\section{Metode Pengumpulan dan Instrumen Pengumpulan Data}

Metode pengumpulan data yang dipakai dalam penelitian ini adalah metode survei dilakukan dengan pengambilan data melalui penyebaran daftar pertanyaan yang ditujukkan ke obyeknya.

Sebagai alat instrumen dalam penelitian ini adalah menggunakan kuisioner seperti yang ada pada lampiran. Dalam penyusunan kuisioner menggunakan skala yang mengacu pada skala likert dengan indeks nilai dari 1 sampai 5. Skala likert merupakan skala yang dipakai untuk mengukur sikap, pendapat, dan persepsi seseorang/sekelompok orang tentang fenomena sosial (Sugiyono, 2004). Penggunaan skala pengukuran ini dengan pertimbangan bahwa skala tersebut sudah mempunyai interval. Variabelnya bersifat continue dan tidak dikotom. Dengan menggunakan ukuran yang mempunyai interval tersebut sudah memungkinkan untuk meng- ukur tingkatan preferensi yang paling rendah sampai yang paling tinggi.

Hal ini berarti, jika responden mempunyai preferensi yang kuat maka jawaban mereka adalah setuju atau sangat setuju, sedangkan apabila jawaban mereka adalah ragu-ragu/netral, tidak setuju atau sangat tidak setuju maka berarti tidak ada preferensi pada variabel tersebut.

Instrumen yang akan dipakai untuk pengumpulan data, sebelum digunakan diuji terlebih dahulu melalui riset pendahuluan validitas serta reliabilitasnya, sebagai berikut:

\section{Uji Validitas}

Dari hasil tabel di bawah ini menunjukkan bahwa pengujian validitas untuk variabel yang diidentifikasi mempengaruhi keputusan pembelian sepeda motor Suzuki semua item valid, karena memiliki nilai r-hitung lebih besar dari $r$ tabel ( $r$ hitung $>r$ tabel).

Tabel 2. Hasil Pengujian Validitas Kuisioner.

\begin{tabular}{lccc}
\hline Variabel (X1) & r hitung & r tabel & Status \\
\hline Harga 1 & 0,871 & 0,396 & Valid \\
Harga 2 & 0,867 & 0,396 & Valid \\
Harga 3 & 0,848 & 0,396 & Valid \\
Kualitas 1 & 0.877 & 0,396 & Valid \\
Kualitas 2 & 0,901 & 0,396 & Valid \\
Kualitas 3 & 0,933 & 0,396 & Valid \\
Desain 1 & 0,839 & 0,396 & Valid \\
Desain 2 & 0,933 & 0,396 & Valid \\
Desain 3 & 0,902 & 0,396 & Valid \\
Kemudahan & 0,951 & 0,396 & Valid \\
perawatan 1 & & & \\
Kemudahan & 0,926 & 0,396 & Valid \\
Perawatan 2 & & & \\
Kemudahan & 0,956 & 0,396 & Valid \\
perawatan 3 & & & \\
Kenyamanan 1 & 0,765 & 0,396 & Valid \\
Kenyamanan 2 & 0,905 & 0,396 & Valid \\
Kenyamanan 3 & 0,802 & 0,396 & Valid \\
\hline
\end{tabular}


Uji Reliabilitas

Hasil pengujian reliabilitas instrument pertanyaan dapat didiskripsikan ke dalam tabel sebagai berikut:

Tabel 3. Hasil Pengujian Reliabilitas Instrument Pertanyaan.

\begin{tabular}{lcc}
\hline \multicolumn{1}{c}{ Instrumen } & Cronbach's $\boldsymbol{\text { Alpha }}$ & Keterangan \\
\hline Keputusan Pembelian (Y) & 0,673 & Reliabel \\
Harga (X1) & 0,871 & Reliabel \\
Kualitas (X2) & 0,938 & Reliabel \\
Desain (X3) & 0,826 & Reliabel \\
Kemdahan Perawatan (X4) & 0,882 & Reliabel \\
Kenyamanan (X5) & 0,761 & Reliabel \\
\hline
\end{tabular}

Dari hasil pengujian reliabilitas atas instrumen, dapat diketahui bahwa semua item dalam instrumen adalah reliabel.

\section{Metode Analisis}

Untuk menganalisis keputusan konsumen dalam membeli sepeda motor Suzuki digunakan metode analisis statisik, analisis regresi berganda dan pengujian hipotesis baik secara parsial maupun simultan dengan uji t dan uji F.

\section{Hasil Analisis dan Pengujian Hipotesis}

Berdasarkan hasil perhitungan dengan menggunakan bantuan program SPSS seri 16.0, diperoleh hasil sebagai berikut:

Tabel 4. Hasil Analisis menggunakan Regresi Linier Berganda.

\begin{tabular}{lccccc}
\hline \multicolumn{1}{c}{ Atribut } & Koef. Reg. & SE & B & t-hitung & Sig. \\
\hline Kep. Konsumen (Y) & & & & & \\
Konstan (a) & 3,379 & 0,661 & & 5,112 & 0,000 \\
Harga (X1) & 0,247 & 0,076 & 0,289 & 3,239 & 0,002 \\
Kualitas (X2) & 0,143 & 0,075 & 0,170 & 2,245 & 0,026 \\
Desain (X3) & 0,021 & 0,057 & 0,032 & 1,999 & 0,048 \\
Kem. Perawatan (X4) & 0,009 & 0,062 & 0,014 & 0,153 & 0,879 \\
Kenyamanan (X5) & 0,261 & 0,058 & 0,437 & 4,530 & 0,000 \\
R =0,820 & & & & & \\
$\mathrm{R}^{2}=0,672$ & & & & & \\
Adjust $\mathrm{R}^{2}=0,654$ & & & & \\
$\mathrm{~F}=37,664$ & & & & \\
\hline Sign $=0,000$ &
\end{tabular}

Sumber: Data Primer, telah diolah.

Dari tabel di atas didapat persamaan re- $\quad \mathbf{Y}=\mathbf{a}+\mathbf{b}_{1} \mathbf{X}_{1}+\mathbf{b}_{2} \mathbf{X}_{2}+\mathbf{b}_{3} \mathbf{X}_{\mathbf{3}}+\mathbf{b}_{4} \mathbf{X}_{4}+\mathbf{b}_{5} \mathbf{X}_{5}+\mathbf{e}$ gresi:

$$
Y=3,379+0,289 X 1+0,170 X 2+0,032 X 3+0,014 X 4+0,437 X 5
$$




\begin{tabular}{|c|c|c|c|c|c|}
\hline \multirow{2}{*}{\multicolumn{2}{|c|}{ t-hitung $=$}} & 5,112 & 3,239 & 2,245 & 1,999 \\
\hline & & 0,153 & 4,530 & & \\
\hline \multirow[t]{2}{*}{ Prob. } & $=$ & 0,000 & 0,002 & 0,026 & 0,048 \\
\hline & & 0,879 & 0,000 & & \\
\hline \multirow[t]{2}{*}{$r$} & $=$ & 0,247 & 0,143 & 0,021 & 0,009 \\
\hline & & 0,261 & & & \\
\hline
\end{tabular}

\section{Pengujian Hipotesis Secara Parsial}

Berdasarkan hasil analisis regresi tersebut dapat diketahui peranan masing-masing variabel independen baik secara terpisah maupun bersama-sama terhadap intensitas pembelian konsumen pada sepeda motor Suzuki adalah:

\section{a. Pengaruh Faktor Harga terhadap Kepu- tusan Pembelian.}

Berdasarkan hasil analisis, bahwa faktor tingkat harga $\left(\mathrm{X}_{1}\right)$ adalah variabel yang berpengaruh secara signifikan terhadap keputusan konsumen dalam pembelian sepeda motor suzuki yang ditunjukkan dengan nilai t hitung $(3,239)$ lebih besar dibanding dengan nilai $\mathrm{t}$ tabel $(1,685)$ dengan tingkat prob. 0,002, besarnya pengaruh sebesar 0,289. Faktor harga dibanding faktor yang lain, dilihat dari koefisien nilai $r$ sebagai indikator determinasi dalam keputusan pembelian, mempunyai kekuatan pengaruh sebesar 0,247 atau sebesar 24,7\%. Hal ini telah menunjukkan $24,7 \%$ keputusan pembelian sepeda motor Suzuki oleh konsumen ditentukan oleh faktor harga yang ditawarkan.

\section{b. Pengaruh Faktor Kualitas terhadap Kepu- tusan Pembelian.}

Berdasarkan hasil analisis, bahwa faktor tingkat kualitas adalah variabel yang berpengaruh secara signifikan terhadap keputusan konsumen dalam pembelian sepeda motor Suzuki yang ditunjukkan dengan nilai t hitung 2,245 lebih besar dibanding dengan nilai $\mathrm{t}$ tabel $(1,685)$ dengan tingkat prob. 0,026 , besarnya pengaruh yang ditunjukkan dengan nilai koefisiennya sebesar 0,170. Faktor kualitas dibanding faktor yang lain, dilihat dari koefisien nilai $r$ sebagai indikator determinasi dalam keputusan pembelian, mempunyai kekuatan pengaruh sebesar 0,143 atau sebesar $14,3 \%$. Hal ini menun- jukkan 14,3\% keputusan pembelian sepeda motor Suzuki oleh konsumen ditentukan oleh faktor persepsi atas kualitas.

\section{c. Pengaruh Faktor Desain terhadap Kepu- tusan Pembelian.}

Berdasarkan hasil analisis, bahwa faktor desain adalah variabel yang berpengaruh secara signifikan terhadap keputusan konsumen dalam pembelian sepeda motor Suzuki yang ditunjukkan dengan nilai t hitung 1,949 lebih besar dibanding dengan nilai $t$ tabel $(1,685)$ dengan tingkat prob. 0,048 , besarnya pengaruh sebesar 0,032 . Faktor desain dibanding faktor yang lain, dilihat dari koefisien nilai $r$ sebagai indikator determinasi dalam keputusan pembelian, mempunyai kekuatan pengaruh sebesar 0,21 atau sebesar $21 \%$. Hal ini menunjukkan $21 \%$ keputusan pembelian sepeda motor Suzuki oleh konsumen ditentukan oleh faktor desain yang ditampilkan.

\section{d. Pengaruh Faktor Kemudahan Perawatan terhadap Keputusan Pembelian.}

Berdasarkan hasil analisis, bahwa faktor kemudahan perawatan adalah variabel yang tidak berpengaruh secara signifikan terhadap keputusan konsumen dalam pembelian sepeda motor Suzuki yang ditunjukkan dengan nilai t hitung 0,153 lebih kecil dibanding dengan nilai $\mathrm{t}$ tabel $(1,685)$ dengan tingkat prob. 0,879 , besarnya pengaruh yang ditunjukkan dengan nilai koefisiennya sebesar 0,014 . Faktor kemudahan perawatan, dilihat dari koefisien nilai $r$ sebagai indikator determinasi dalam keputusan pembelian mempunyai kekuatan pengaruh sebesar $=0,009$ atau sebesar $0,9 \%$. Hal ini menunjukkan $0,9 \%$ keputusan pembelian sepeda motor Suzuki oleh konsumen ditentukan oleh faktor keyakinan konsumen atas kemudahan perawatan.

\section{e. Pengaruh Faktor Kenyamanan terhadap Keputusan Pembelian.}

Berdasarkan hasil analisis, bahwa faktor kenyamanan adalah variabel yang berpengaruh secara signifikan terhadap keputusan konsumen dalam pembelian sepeda motor Suzuki yang ditunjukkan dengan nilai $t$ 
hitung 4,530 lebih besar dibanding dengan nilai $\mathrm{t}$ tabel $(1,685)$ dengan tingkat prob. 0,000 , dan besarnya pengaruh sebesar 0,437. Faktor kenyamanan dibanding faktor yang lain, dilihat dari koefisien nilai $r$ sebagai indikator determinasi dalam keputusan pembelian, mempunyai kekuatan pengaruh sebesar 0,261 atau sebesar 26\%. Hal ini menunjukkan $26 \%$ proporsi keputusan pembelian sepeda motor Suzuki oleh konsumen ditentukan keyakinan konsumen akan kenyamanan atas sepeda motor Suzuki.

\section{Pengujian Secara Simultan}

Dari hasil olah data diperoleh $\mathrm{F}$ hitung adalah 37,664 dengan tingkat signifikan 0 , 000 , karena probabilitas $(0,000)$ jauh lebih kecil dari 0,05, maka model regresi tersebut dapat dipakai untuk memprediksi keputusan pembelian, atau dapat dikatakan bahwa faktor harga, kualitas, desain, kemudahan perawatan dan kenyamanan secara bersamasama berpengaruh secara signifikan terhadap keputusan pembelian sepeda motor Suzuki. Sedangkan besarnya diterminasi atas faktorfaktor tersebut bagi konsumen dalam keputusan pembelian sepeda motor Suzuki adalah sebesar 0,654 atau sebesar $65,4 \%$, yang artinya bahwa sebesar $65,4 \%$, keputusan konsumen membeli sepeda motor Suzuki dapat dijelaskan oleh faktor harga, kualitas, desain, kemudahan perawatan dan kenyamanan. Sedangkan sisanya $34,6 \%$ dipengaruhi/dijelaskan oleh variabel lain yang tidak dimasukkan dalam model penelitian ini

\section{Kesimpulan}

Berdasarkan analisis terhadap pengaruh berbagai atribut sepeda motor Suzuki seperti faktor harga, kualitas, desain, kemudahan perawatan dan kenyamanan, secara individual, masing-masing diketahui bahwa faktor harga, kualitas, desain, serta kenyamanan, mempunyai pengaruh yang signifikan terhadap keputusan konsumen dalam membeli sepeda motor Suzuki, hanya untuk faktor kemudahan dalam perawatan tidak signi- fikan. Hal ini bisa jadi faktor kemudahan perawatan pada sepeda motor adalah faktor yang relatif tidak dapat dibedakan antar merek sepeda motor sehingga tidak mempunyai aspek khusus antar merek sepeda motor. $\mathrm{Na}-$ mun jika dilihat kelima variabel tersebut secara simultan maka semua variabel tersebut mempunyai pengaruh yang signifikan sehingga layak sebagai variabel prediktor.

Di antara variabel yang diperhatikan, atribut kenyamanan adalah variabel yang paling besar proporsi pengaruhnya dalam keputusan pembelian di antara variabel-variabel lainnya bagi konsumen dalam membeli sepeda motor Suzuki. Berarti kenyamanan berkendara sepeda motor Suzuki dapat dibedakan secara nyata dibanding dengan sepeda motor merek lainnya dan sepeda motor Suzuki dirasakan lebih nyaman. Seperti jika naik sepeda motor yang lain biasanya getarannya lebih kuat menjadikan kesemutan sedangkan kalau Suzuki lebih halus tidak mudah kesemutan. Hal ini sebaiknya dipakai oleh manajemen untuk menjadikan faktor pembeda bagi sepeda motor Suzuki yang dapat meningkatkan daya saingnya. Faktor harga sebagai variabel berikutnya yang dipertimbangkan oleh konsumen dalam membeli sepeda motor Suzuki. Tingkat harga sepeda motor Suzuki memang lebih rendah dibanding dengan merek Honda maupun Yamaha, sehingga hal ini menjadi salah satu pendorong bagi konsumen dalam pengambilan keputusan pembelian sepeda motor.

\section{Daftar Pustaka}

Arikunto, Suharsimi. 2006. Prosedur Penelitian suatu Pendekatan Praktek. Edisi revisi VI. Jakarta: PT. Rineka Cipta.

Bayton. James A. (1982). "Motivation, Cognition, Learning-Basic Factors in Consumer Behavior." dalam James U. McNeal and Stphen W. McDaniel (eds.). Consumer Behavior: Clasical and Contemporary Dimensins. Boston. Massachussets: Little Brown and Company.

Dharmestha, B. S. (1993). "Perilaku 
Berbelanja Konsumen Era 90-an dan Strategi Pemasaran."Jurnal Ekonomi dan Bisnis Indinesia. No. 1 Tahun VII.

Engel, J. F; R. D. Blackwell; P. W. Miniard. 1992. Consumer Behavior. Florida. Orlando: The Dryden Press.

Fandy, Tjiptono. 2002. Strategi Pemasaran. Yogyakarta: Andi Offset.

Kotler, Philip. 1994. Marketing Management: Analysis, Planning, Implementation, And Control. $8^{\text {th }}$ Ed. Englewood Cliffs. New Jersey: Prentice Hall International Editions.

Kotler dan Keller. 2009. Manajemen Pemasaran, edisi 13. Jakarta: Erlangga.

Loudon, D. L., A. J. Della Bitta. 1993. Consumer Behavior: Concept and Applications. $4^{\text {th }}$ Ed. New York: McGraw Hill.

McNeal, James U, and Stephen W, McDaniel. 1982. "Murray's Theory of Human Needs: A Useful Guide to Understanding Consumer Behavior," dalam James U, McNeal and Stephen W. McDaniel (eds.). Consumer Behavior: Classical and Contemporary Dimentions. Boston. Massachussets: Little Brown and Company.

Mindak, William A. (1992). "Fitting the Semantic Differential to the Marketing Problem." Dalam James U, McNeal and Stephen W. McDaniel (eds.). Consumer Behavior: Classical and Contemporary Dimentions. Boston. Massachussets: Little
Brown and Company.

Sands, Saul. 1982. "Motivation Research in Marketing: Fact and Fancy." dalam James U, McNeal and Stephen W, McDaniel (eds.). Consumer Behavior: Classical and Contemporary Dimensions. Massachussets. Boston: Little Brown and Company.

Sekaran, Uma. 2003. Researc Method for Bussines: A skill Bulding Approach. $4^{\text {rd }}$ Edition. New York: John Wiley \& Sons.

Sugiyono. 2007. Statistika untuk Penelitian. Bandung: CV. ALFABETA.

Tauber, Edward M. (1982). "Why do People Shop?" dalam James U, McNeal and Stephen W. M. (eds.). Consumer Behavior: Classical and Contemporary Dimensions. Boston Massachussets: Little Brown and Co., page: 144-150.

Zeithaml, Valarie A. (1986). "Consumer Perception of Price Quality and Value: A Means-End Model and Synthesis of Evidence." Journal of Marketing. July, Volume 52. Number 2, page: 2-22.

http://oto.detik.com/read/2013/10/09/142538 /2382484/1208/penjualan - motor-turunada-apa-suzuki?

http://proud2rideblog.com/2012/12/11/Mark et- Share- Penjualan- Motor All- Brand Sesuai- \#AISI November

http://aisi.co.id. 